\title{
Whales vs. gulls: Assessing trade-offs in wildlife and waste management in Patagonia, Argentina
}

\author{
Stephanie F. Stefanski ${ }^{a, *, 1}$, Sebastian Villasante ${ }^{\mathrm{b}, c, \mathrm{~d}}$ \\ ${ }^{a}$ Yale School of Forestry \& Environmental Studies, 195 Prospect St., New Haven, CT 06511, United States \\ ${ }^{\mathrm{b}}$ Universidad de Santiago de Compostela, Av Angel Echevarry s/n., Santiago de Compostela, 15782 A Coruña, Spain \\ c Campus Do*Mar-International Campus of Excellence, Pontevedra, Spain \\ ${ }^{\mathrm{d}}$ Natural Capital Fellow-Natural Capital Project, 371 Serra Mall, Stanford University, Stanford, CA 94305-5020, United States
}

\section{A R T I C L E I N F O}

\section{Article history:}

Received 1 June 2014

Received in revised form

12 November 2014

Accepted 22 November 2014

\section{Keywords:}

Wildlife management

Patagonia

Argentina

Economic valuation

Contingent valuation

\begin{abstract}
A B S T R A C T
In Península Valdés, (Patagonia) Argentina, the consequences of poor waste management and an overpopulation of kelp gulls has led to gulls feeding on living southern right whales, potentially causing losses to the tourism industry through loss in coastal quality and suboptimal right whale viewing experiences. Despite local progress in closing waste disposal sites and culling gulls, both waste and pest problems persist. While this problem could impact the long-term viability of the site as a whale watching destination and present conservation concerns, little research has been done concerning the socio-economic aspects of the problem. The present study interviewed 650 tourists about their willingness to pay to manage the gulls versus the waste in order to reduce the gull population and remove the risk to the whales. This research finds that tourists favor addressing the human-driven component of the problem, the waste, over culling the natural component of the problem, the kelp gulls. These findings present a remarkable insight to assessing trade-offs between two management strategies to a local problem associated with coastal development and tourism. The results could further be broadened to other destinations facing waste and pest management challenges in the face of growing tourism and urbanization.
\end{abstract}

(c) 2014 Published by Elsevier B.V.

\section{Introduction}

Tourism worldwide is a growing component of local economies and driver of development, especially along coastlines. While tourism supports livelihoods and can incentivize conservation through better management of nature parks, it also challenges local governments unaccustomed to the pressures of high tourist volume. Consequently, tourism and accompanying urbanization are generating adverse consequences in once pristine natural areas (Davenport and Davenport, 2006; Holden, 2008). To sustainably manage development in these ecosystems, resource managers need to better understand the feedback loops between ecosystem health and tourism. Economic valuation studies, which survey residents and visitors, can provide insight about non-market values generated by indirect uses, such as recreation and aesthetics, in order to conduct cost-benefit analyses of the trade-offs in management policies. The present study implements a simple contingent valuation survey in a coastal protected area and tourism destination in Patagonia, Argentina in

\footnotetext{
* Corresponding author.

E-mail address: Stephanie.Stefanski@duke.edu (S.F. Stefanski).

${ }^{1}$ Current address: Duke University, Nicholas School of the Environment, Box 90328 Durham, NC 27708, United States.
}

order to assess trade-offs between different management and conservation strategies.

In coastal areas, tourism impacts often include littering, emissions from vehicles and boats, and increased demand for local water and food resources (Byrnes and Warnken, 2006; Holden, 2008). These threats are especially evident in popular destinations in Latin America, such as the Galapagos, Costa Rica, and Brazil. The study site, Península Valdés, is a protected UNESCO (United Nations Educational, Scientific, and Cultural Organization) World Heritage Site located in the Chubut Province of Patagonia, Argentina. The Peninsula, an area of $4000 \mathrm{~km}^{2}$, features important coastal habitat for marine mammals, including Southern right whales (Eubalaena australis), Southern elephant seals (Mirounga leonina), South American sea lions (Otaria flavescens), and orcas (Orcinus orca).

Tourism began to develop in Península Valdés in the 1970s as part of a growing interest in viewing, rather than hunting, marine mammals in their natural habitats (Kuper, 2009). Prior to 1960s federal legislation, sea lions and right whale were commercially exploited (Schluter, 1999). Shortly thereafter, the Secretary of Tourism was established to oversee environmental protection and tourism development (Schluter, 1999). Research interests, including the New York Zoological Society and the National 
Patagonia Center (CENPAT), developed in the 1960s and 1970s to study the marine mammal populations. These initiatives later informed the Avistaje patagonico ${ }^{2}$ model of whale watching, a method practiced by pioneer Argentine outfitters in Puerto Pirámides, the only town in Península Valdés. These efforts were accompanied by growing regulation of boating and fishing activities within the San Jose Gulf of Península Valdés, culminating in the 1999 designation as a World Heritage Site.

However, despite federal laws and local efforts to implement responsible tourism practices, threats to the long-term conservation of marine mammals and coastal ecosystem persist. Research demonstrates that fishery activities, tourism operations, and pollution threaten Magellanic penguins (Spheniscus magellanicus), other marine birds, Dusky dolphins (Lagenorhynchus obsucrus), and Southern right whales throughout coastal Patagonia (Coscarella et al., 2003; Dans et al., 2003; Gandini et al., 2011; Sironi et al., 2011, 1998).

While fisheries may cause direct mortality of marine mammals through entanglement, pollution from tourism and population growth, in addition to discards from fishery operations, generates more ubiquitous effects on the region. Inadequate recycling and waste management facilities in cause the proliferation of open-air waste disposal sites outside of the Península Valdés protected area. These waste sites serve as a food source that supplements the kelp gull (Larus dominicanus) population (Fig. 1) (Lisnizer et al., 2011). This overpopulation of kelp gulls in Península Valdés region in turn has led to a growing number of gulls attacking and feeding on the living flesh of right whales, a behavior first recognized in the early 1970s (Rowntree et al., 1998; Sironi et al., 1998; Thomas, 1988). Further evidence demonstrates that gulls prefer feeding on the more vulnerable flesh of calves (Fig. 2) and tend to target mother-calf pairs of right whales (Fazio et al., 2012; Sironi et al., 1998). Although the consequences of this parasitic relationship between gulls and whales is unknown, it is but one of several factors potentially contributing to a growing mortality rate of Southern right whale calves in the Península Valdés region, which reached a 10-year high in 2013 with 113 dead calves (Fazio et al., 2012; Rowntree et al., 2013; Sironi et al., 1998).

The scientific uncertainty concerning the right whale mortality and the kelp gull-right whale relationship poses a significant challenge to local policymakers and park administration. While kelp gulls can be considered pests, they are naturally occurring species that serve ecological functions and add to the aesthetics of the coastal landscape valued by tourists. Local experimental efforts to target and kill kelp gulls specifically attacking right whales has been met with controversy and little success (interviews with local whale watching guides and residents). It seems unlikely that either complete gull population control or improved waste management will resolve the problem, and that the solution lies in implementing strategies that address both issues-the humancaused waste issue and the naturally-occurring pest problem.

It appears that the kelp gull attacks on whales potentially degrades the whale watching experience and that poor waste management could affect aesthetic qualities of this site. As a result, tourists should be considered one of the primary stakeholders in this management dilemma. This consideration led to the present study, which surveyed 656 tourists about their perceptions on environmental problems in the area and their preferences for a management plan that would address the gull population problem through (a) improved waste management, (b) direct gull culling, or (c) some unspecified strategy to reduce the attacks. The results demonstrate the controversial nature of this problem and the

\footnotetext{
${ }^{2}$ Patagonian whale watching (avistaje patagonico) is a special technique involving tractors to haul ships in and out of the beach. It also includes guidelines for captains to follow when interacting with southern right whales in order to prevent harassment or injury of the whales.
}

strong preferences of tourists to address the human-caused issue, waste, over naturally occurring phenomena. The results provide interesting insight for other tourist destinations managing pest and waste problems associated with population and tourism growth, in which policymakers and resource managers need to assess tradeoffs between different management plans.

\section{Material and methods}

The present study is part of a larger study analyzing the value of recreational services and wildlife viewing at Península Valdés. Data for the study was collected via in-person surveys in Puerto Madryn, the main town outside of Península Valdés for tourist accommodations, and Puerto Pirámides, the main whale watching port. The principal author and four trained assistants conducted 656 surveys in English, Spanish, and French with tourists in Puerto Madryn and Puerto Pirámides. Each survey was five pages long and took 15 to $20 \mathrm{~min}$ to complete (Appendix A). Final survey design was based on feedback from resource economists and local researchers in Puerto Madryn and from a pre-test survey, which collected 100 responses in June 2014. The survey was conducted July through October 2014, at the height of the whale-watching season (June-December).

The survey was divided into five sections: (1) warm-up; (2) sociodemographic questions; (3) travel cost questions; (4) species contingent valuation; (5) management plan contingent valuation. The fifth and final section of the survey addressed the gull and whale issue through a close ended and open ended contingent valuation willingness to pay (WTP) question. Question design followed literature recommendations (Arrow et al., 1993), and its section consisted of a warm up question, brief informational section about the issue, and a description of three management plans, each with the goal of indirectly or directly managing the gull population: a general plan, Plan A to improve waste management, and Plan B to shoot "attacker gulls". The general plan does not describe how the situation will be managed, only that funds from the park entrance fee will be directed towards some type of program to reduce the population. The study utilized five separate versions of the survey. Each survey was identical except for the initial proposed fee for the management plan. Survey versions $[A, B, C, D, E]$ were randomly assigned the amount $X$ in Argentine pesos (ARG \$) $[55,100,75,25,15]$, respectively $^{3}$. Each survey respondent was randomly assigned one of the five versions of the survey.

The opening dialogue of the question read:

There is evidence that kelp gulls, the most abundant bird in the area, have been attacking whales for food. Recently, government authorities in the province have decided to implement management actions to mitigate gull attacks on the whales.

If it cost $\$ \mathrm{X}$ to reduce the kelp gull population, would you pay this amount as an additional charge included in the entrance fee, with the sole purpose of being used to reduce the kelp gull population? [YES/NO]

After answering yes or no to the general management plan, respondents were then asked how much they would pay for Management Plan A, which would improve management of local disposal waste sites so it would no longer be a feeding site for gulls. Then, assuming this plan were not sufficient to address the problem, respondents were asked much they would pay for Management Plan B, which would reduce the gull population by shooting attacker gulls.

\footnotetext{
${ }^{3}$ At the time of the survey, the average exchange rate from July to October
} 2013 was ARG \$5.62 for USD \$1.00. 


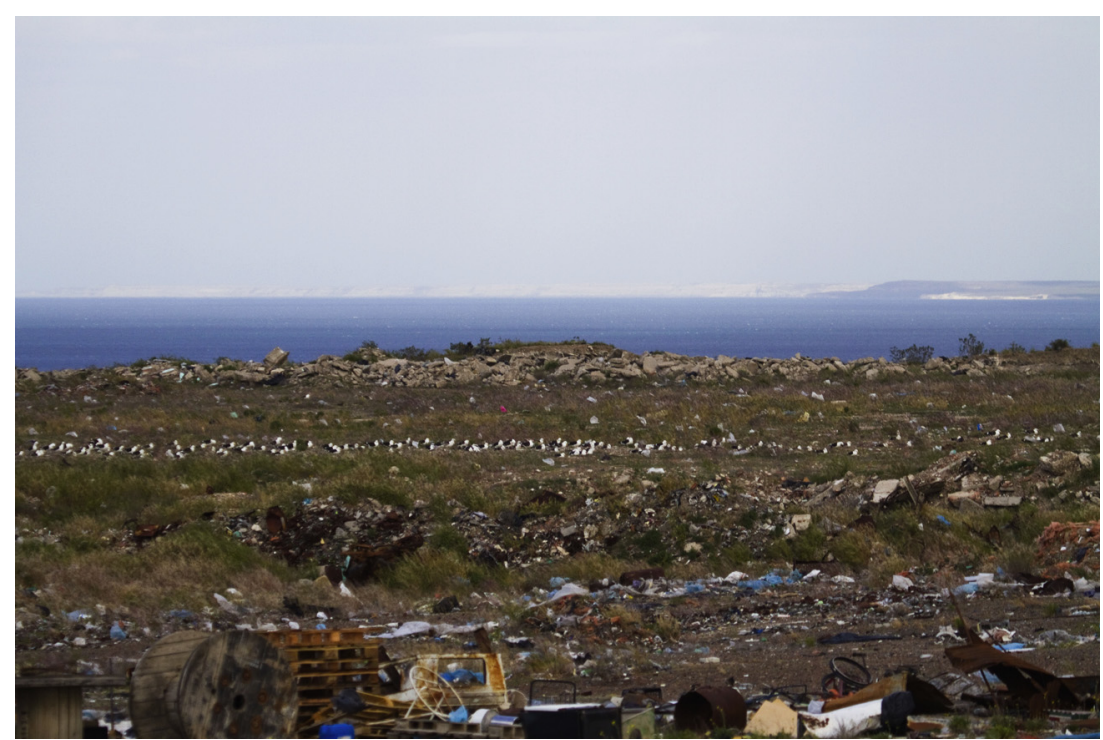

Fig. 1. Flock of kelp gulls at one of the open-air waste sites outside of the Península Valdés protected area.

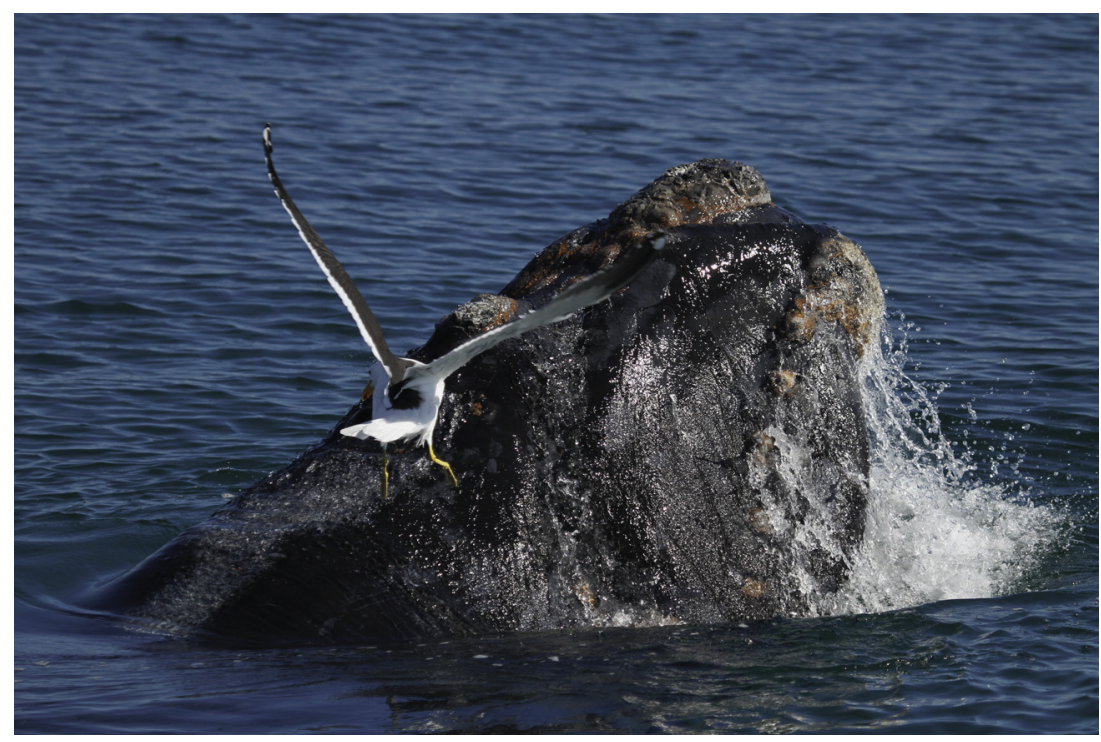

Fig. 2. Kelp gull feeding on the skin of a southern right whale calf.

For the general plan, logit analysis is used to determine the mean WTP estimate of the close-ended, or dichotomous, WTP question (Haab and McConnell, 2003). Given a linear WTP function, WTP is a function of a set of parameters, where $z$ represents a matrix of socio-demographic covariates, $\eta$ is an error term and $\gamma$ represents the coefficient on the matrix, for each respondent $j$ :

$\operatorname{WTP}\left(z_{j}, \eta_{j}\right)=\gamma z_{j}+\eta_{j}$

Mean WTP is then calculated with the coefficients on matrix $z(\gamma / \sigma)$ and the coefficient on the offered bid $t(-1 / \sigma)$ :

$E_{\eta}\left(\mathrm{WTP} \mid z_{j}, \gamma\right)=\frac{(\hat{\gamma} / \sigma)}{(\hat{1} / \sigma)} z$

For the specific plans, a general regression model is used for the open-ended responses. Results are tested for significant sociodemographic characteristics and differences between Argentine and international visitors. The open-ended WTP estimates for Management Plans A and B are calculated through linear regression on the given bid and a suite of socio-economic characteristics (Model 1). The given bid for the general
Management Plan is included since it is expected to have an anchoring effect on responses.

\section{Results}

Survey results revealed insight to the management dilemma from the perspective of tourists. Regression results demonstrate significant WTP values for a management plan that would address the gull population problem, specifically through improved waste management (Table 1). Open-ended conversations with tourists in the debriefing portion of the survey after the questionnaire revealed generally negative responses to culling the gulls, especially by international tourists who considered the gulls part of the natural aesthetics and biodiversity they travelled so far to view, even though the kelp gulls are neither endangered or unique to the region. It is apparent that tourists are much more in favor of addressing the human-caused waste management problem rather than the natural component of the problem-gulls attacking whales. These conversations with tourists concerning their viewpoints about the plans are consistent with the actual responses 
Table 1

Logit and regression results for general management plan, management Plan A, and management Plan B.

\begin{tabular}{|c|c|c|c|c|c|c|}
\hline & $\begin{array}{l}\text { General plan } \\
\text { (1) }\end{array}$ & $\begin{array}{l}\text { General plan } \\
\text { (2) }\end{array}$ & $\begin{array}{l}\text { Plan A } \\
\text { (3) }\end{array}$ & $\begin{array}{l}\text { Plan A } \\
(4)\end{array}$ & $\begin{array}{l}\text { Plan B } \\
\text { (5) }\end{array}$ & $\begin{array}{l}\text { Plan B } \\
(6)\end{array}$ \\
\hline Bid & $\begin{array}{l}-0.0615^{\text {***** }} \\
(-3.86)\end{array}$ & $\begin{array}{l}-0.0631^{* * * *} \\
(-3.98)\end{array}$ & $\begin{array}{l}0.427^{* * * * *} \\
(6.21)\end{array}$ & $\begin{array}{l}0.422^{* * * *} \\
(6.38)\end{array}$ & $\begin{array}{l}0.238^{* * * * *} \\
(3.36)\end{array}$ & $\begin{array}{l}0.222^{* * *} \\
(3.26)\end{array}$ \\
\hline Argentine resident & $\begin{array}{l}0.240 \\
(1.13)\end{array}$ & & $\begin{array}{l}0.834 \\
(0.89)\end{array}$ & & $\begin{array}{l}2.264^{*} \\
(2.34)\end{array}$ & \\
\hline Income & $\begin{array}{l}0.000 \\
(1.07)\end{array}$ & & $\begin{array}{l}0.000 \\
(0.05)\end{array}$ & & $\begin{array}{l}0.000 \\
(0.32)\end{array}$ & \\
\hline College education & $\begin{array}{l}-0.0029 \\
(-0.01)\end{array}$ & & $\begin{array}{l}1.181 \\
(1.32)\end{array}$ & & $\begin{array}{l}-0.338 \\
(0.37)\end{array}$ & \\
\hline Age & $\begin{array}{l}0.002 \\
(0.22)\end{array}$ & & $\begin{array}{l}-0.0075 \\
(-0.25)\end{array}$ & & $\begin{array}{l}-0.028 \\
(-0.89)\end{array}$ & \\
\hline Constant & $\begin{array}{l}0.960^{*} \\
(2.28)\end{array}$ & $\begin{array}{l}1.328^{* * * * *} \\
(7.17)\end{array}$ & $\begin{array}{l}1.235 \\
(0.68)\end{array}$ & $\begin{array}{l}2.54^{* * * * *} \\
(3.33)\end{array}$ & $\begin{array}{l}-0.332 \\
(-0.18)\end{array}$ & $\begin{array}{l}0.770 \\
(1.02)\end{array}$ \\
\hline $\mathrm{N}$ & 611 & 611 & 602 & 625 & 602 & 625 \\
\hline$p$-Value & & & 0.00 & 0.00 & 0.006 & 0.001 \\
\hline$R$-sq & & & 0.064 & 0.061 & 0.027 & 0.019 \\
\hline Log likelihood & -379.284 & -380.375 & & & & \\
\hline Mean WTP (USD) & $\$ 21.33$ & $\$ 21.04$ & $\$ 6.56$ & $\$ 6.53$ & $\$ 2.90$ & $\$ 2.91$ \\
\hline
\end{tabular}

$t$ statistics in parentheses.

$* p<0.05$.

$* * p<0.01$.

$* * * * * \quad p<0.001$.

tourists gave in the WTP portion of the survey, where the management plan received a higher percentage of "yes" responses than the culling plan. However, it is also interesting to note that, especially among those not willing to pay any amount, several international tourists, through informal comments, viewed the waste management problem as the city's responsibility and not an outcome of tourism activity.

Regardless of the methods, tourists largely favored the vague general plan to manage the gull population, as apparent through the high WTP estimate of USD \$21. Although this value appears low, it must be considered relative to the current entrance fee (Table 2). Entrance fees to Península Valdés are higher for international visitors than for national visitors. At the time of the survey (June-October 2013), Argentine tourists were charged 40 pesos ( US\$7.12) and international tourists were charged 135 pesos ( $\sim$ US\$ 24). Despite differential entrance fees for national and international visitors, the dummy variable Argentine resident is not significantly correlated with WTP for the general plan or Plan A.

As expected, demand for the general plan is decreasing as the initial bid offered increases (Fig. 3). Respondents answered yes or no to a randomly assigned bid for the general plan and then were given the option to respond with any value for Plans A and B. When respondents were faced the choice between Plan A, which would improve waste management, and Plan B, which would cull attacker gulls, respondents were much more willing to pay for Plan A, as demonstrated by the WTP of about USD \$6.50. On the other hand, respondents were only WTP about USD \$2.90 for Plan $B$, less than half the amount they would pay for the preferred Plan A. In addition, it appears that Argentine tourists are slightly significantly more willing to pay for Plan A than Plan B (Table 1, Model 5). This is consistent with the verbal responses of international tourists during the survey debrief. It is also interesting to note that significantly more national tourists (17\%) viewed Kelp gulls as an environmental threat than international tourists (5\%), as given in the warm-up question from this section. In addition, significantly more international tourists (59\%) did not view any environmental threats in the region. In this study, income, college education, and age are not significant determinants of WTP estimates (Table 1 ).
Table 2

Comparison of new fees across management plans and status quo.

\begin{tabular}{lcl}
\hline USD \$ & Domestic visitors & International visitors \\
\hline Current fee & 7.00 & 24.00 \\
Fee+general management plan & 28.04 & 45.04 \\
Fee + Plan A & 13.53 & 30.53 \\
Fee + Plan B & 9.90 & 26.90 \\
\hline
\end{tabular}

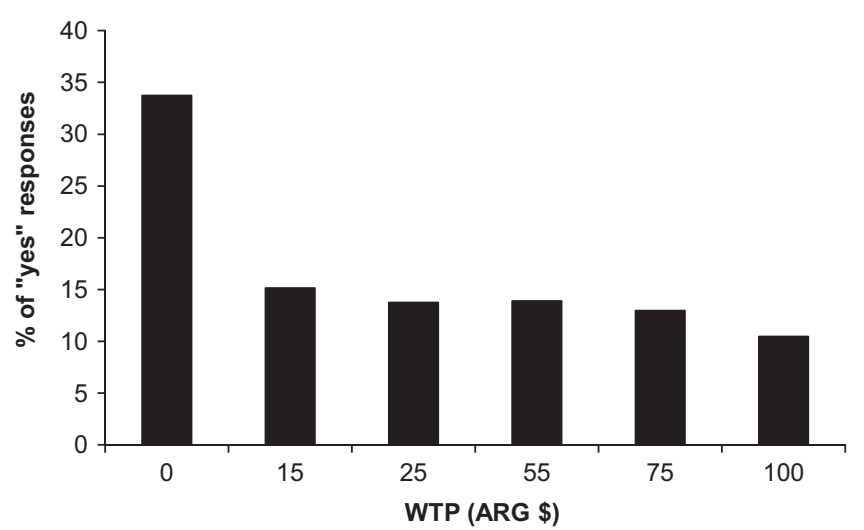

Fig. 3. Percentage of respondents willing to pay for the general plan under each bid.

Given the current entrance fee, these WTP estimates represent a potential increase in the fee by a significant amount in order to fund better resource management policies (Table 2). If any given plan were to be implemented, the WTP estimate for that plan would be added to the existing fee of $\$ 7$ for domestic visitors and $\$ 24$ for international visitors. For example, the WTP for the general plan would nearly triple the current fee for Argentine visitors (increasing it from $\$ 7$ to $\$ 31$ ) while only increasing the international visitors fee by less than double the current fee (Table 2). While these percentages differ across plans and visitor types, 
the resulting WTP values demonstrate significant implications for financing different management plans.

\section{Discussion}

The results from this study demonstrate significant WTP estimates for different management plans to address the waste management problem in the region outside of Península Valdés. These results fall in line with previous literature studies on entrance fees as vehicles for conservation and park management in addition to providing insight to the drivers of WTP for such actions (Naidoo and Adamowicz, 2005; Ormsby and Mannle, 2006; Thur 2010; Walpole et al., 2001). Rather than address the direct threat, the 'attacker gulls', tourists preferred to target the human-caused component of the problem-the waste. Whether or not the waste management could actually curb the gull population sufficiently to reduce the threat to the right whales may not have mattered as much as the regional ecological and aesthetic benefits associated with improved waste management, as evident by the higher WTP for the generic and waste management plans. Culling the gulls, which many feel are "not to blame" for the problem, does not address the underlying problem in the eyes in the tourists. Instead, they view it as the responsibility of the Administration of Península Valdés and city planners to clean up the waste outside of the park.

While tourism may drive urbanization, population growth, waste generation, and pressure on natural resources, it can also support conservation initiatives. Survey results show that international and national visitors to Península Valdés are aware of environmental issues threatening its viability as a nature tourism destination. International ecotourism destinations, like Península Valdés, can serve as a financing mechanism for conservation through responsible use of entrance fees and integrated management of coastal activities.

A key component of ecotourism is the closed loop nature of revenue. For example, revenues may contribute towards community development or towards maintenance costs of the protected area (Medina, 2005). Several studies demonstrate that entrance fees and other revenue generated by tourism activities benefit both the community and the protected area. For example, Naidoo and Adamowicz (2005) find that revising entrance fees to $\$ 47$ (from the original \$5) and redistributing ecotourism revenues would protect $80 \%$ of forest bird species. Another study calculates that a modest increase in entrance fees for a protected area in Indonesia would potentially better finance the site (Walpole et al., 2001). In Masoala National Park (Madagascar), 50\% of entrance fees are allocated to local management committees for development projects such as road improvements, schools, and facilities (Ormsby and Mannle, 2006).

In addition, tourists are willing to pay more for ecotourism destinations with such sustainable tourism operations and local community involvement (Tourism in the Green Economy-Background Report 2012:29). Further research demonstrates that "visitors would be more willing to pay a higher fee if the revenue generated was used for the benefit of the visited area" (Walpole et al., 2001). This general finding is concurrent with both the results of the present study and the general literature on WTP for protected areas in the tropics and coastal areas.

The majority of such coastal valuation studies focus on WTP for tropical coral reefs or beach aesthetics. For example, Loomis and Santiago (2013) surveyed tourists on WTP for different quality changes in beach aesthetics. On average, trash removal added a value of \$98-\$103 per beach visitor day and improved water quality added \$51-\$54 (Loomis and Santiago, 2013). Several studies have demonstrated a range of WTP values for habitat quality in the
Bonaire National Marine Park (BNMP) in the Caribbean. These studies elicited WTP for improved quality in exchange for increased user fees to the park. The results found that users were WTP an average of \$27 to $\$ 33.50$ per visit or $\$ 61-\$ 134$ for an annual pass (Dixon and Hof, 1993; Thur, 2010; Uyarra et al., 2010). While some of the estimates found in these studies are much higher than those found in the present study (Table 2), each study demonstrates the importance of beach cleanliness and habitat quality as key drivers of WTP for visits to coastal protected areas.

Marine protected areas (MPAs) and parks, like Peninsula Valdes, are one management strategy to generate revenues for conservation while maintaining the integrity of marine habitats. While MPAs can limit access to a site through boundaries and entrance fees, the success of MPAs depends on implementation, monitoring, and enforcement. As a result, proper pricing of entrance fees is required to ensure that the park can be financially viable and politically effective in achieving its conservationoriented goals.

In fact, many studies demonstrate visitor WTP to contribute towards MPA maintenance and implementation (Depondt and Green, 2006; Peters and Hawkins, 2009; Ransom and Mangi, 2010; Reid-Grant and Bhat, 2009; Thur, 2010). One comparative analysis of valuation studies evaluates WTP values for MPAs that support diving, snorkeling, and general beach activities across the Caribbean and Gulf of Mexico, Southeast Asia, the Mediterranean, the Pacific, and the Indian Ocean (Peters and Hawkins, 2009). The analysis reveals that WTP values actually surpass current entrance fees on all sites, demonstrating the potential of entrance fees as a payment vehicle for conservation activities associated with MPAs (Peters and Hawkins, 2009). Furthermore, while the use of tourism-generated revenue can be a critical component for conservation financing, tourism development needs to occur in a measured and sustainable manner. Otherwise, externalities from tourism, such as waste generation and urban sprawl, can jeopardize the ecosystem qualities driving tourism in the first place.

The present study and broader literature on WTP for improved environmental quality in protected areas demonstrate the potential of entrance fees and tourism revenue to support conservation activities within these sites. While tourism development can, and has, adversely impacted the environmental quality of the sites that attract it, such economic valuation studies can help resource managers assess the trade-offs of development and conservation and seek better management outcomes that benefit both local communities and conservation initiatives. The present study demonstrates that increased entrance revenues could be used to better manage waste and the gull population, two adverse reactions from tourism development in the region. By targeting these environmental problems, resource managers could better protect the right whale population, a main driver for tourism, and help ensure future livelihoods for those dependent on tourism revenues. The estimates from this study could be used to inform future management plans and pricing policies for the Península Valdés entrance fee in order to secure the long-term viability of the site as a wildlife tourism destination.

The present study is a fairly simple implementation of the contingent valuation method to assess drivers of WTP of visitors to the site in order to better protect southern right whales and maintain the integrity of the site as an ecotourism destination. This study was one part of a five-page long survey and responses may not have been entirely focused on the issue at hand. Future research should focus solely on this information, providing additional information on each plan in order to reduce confusion. Furthermore, a dichotomous bid should be implemented, as recommended by the broader literature on the contingent valuation method, in order to capture more accurate WTP estimates for these different plans. 


\section{Conclusions}

Despite successes in both tourism and marine mammal conservation, significant challenges remain for the Administration of Península Valdés and local governing authorities. Personal interviews reveal that administrators and tourism operators are supportive of improved waste management and more sustainable tourism operations in response to the growing waste and gull population problems. The results of this study demonstrate external values that support these notions and could spur further action for better waste management practices. Tourists' willingness to pay for additional entrance fees, in exchange for conservation of the site's wildlife and aesthetic qualities, can be incorporated into a cost-benefit analysis to estimate the potential net benefits of financing wildlife and waste management.

The results of this study demonstrate the importance tourists place on the protection of the ecosystem and wildlife found nature tourism destinations, and their willingness to pay to ensure its long-term conservation. Economic valuation studies can inform park management and justify increased entrance fees to offset the negative impacts of tourism within the park and development in the surrounding region. The results of this study offer new insights for resource managers and policymakers on the debate surrounding the gull and whale issue. In addition to directing additional funds towards better waste management facilities, incentives could be provided to business owners to implement more sustainable practices and ensure the long-term viability of the site and the livelihoods of local communities.

This study presents three potential management plans to international and national tourists in the Península Valdés World Heritage site. Each plan addressed a major environmental threat in the region (pollution, garbage, gulls attacking whales). The responses demonstrate that it is pertinent for the Administration of Península Valdés and for city authorities to work together towards resolving these issues. By managing local pollution and the gull population, both national and international tourist perceptions of the region would improve, in addition to the ecological benefits associated with such plans. Such quality improvements could justify higher entrance fees, enhancing the welfare for the region, revenue flow of the park, and long-term viability of the wildlife and natural aesthetics.

\section{Acknowledgements}

SS would like to thank Dr. Robert Mendelsohn (Yale University) for their support and advising throughout the survey design, implementation, and analysis processes. SS especially would like to thank her research assistants - Daniela Marini, Mariangeles Lopez, Luli Bossio, Carolina Sibbald, Cande Bulacios, and Gaston Trobbiani - and the Bottazzi Whale Watching company for making it possible to collect 750 surveys (pre-test and final). Lastly, the author would like to thank all of the hostel owners who opened their doors to the research assistants and her to aid in survey distribution. The author also thanks the Yale Tropical Resources Institute and Tinker Field Grant, as well as the Norwegian Research Council, for funding this project. 
Appendix A. Survey instrument

\section{Section I: Introduction}

Hello, I'm [interviewer name]. I am working with Yale University, the National Patagonian Center, and the University of Santiago de Compostela on a research project to study tourism here in Peninsula Valdes. Could you please help me by answering a few questions about your plans and tourism here in Peninsula Valdes? Your answers will be confidential and will only be used for research purposes.

1. Are you a resident of Argentina? [ YES / NO ]

2. Where do you currently live?

City/Town:

Province:

Country:

3. What is your nationality? (Chilean, American, German, etc.)

4. Please fill out the table below concerning what species you have seen or plan to see on this trip. We are also interested in your personal ranking of which of these species you most wanted to see and which of these species you think is the most important to protect.

Please rank them the most important as (1) and the next most important as (2), etc...

If you do not care about an animal, skip that animal.

\begin{tabular}{|l|l|l|l|l|}
\hline Marine Wildlife Already seen Plan to see Rank value in seeing Rank value to protect \\
\hline Southern right whale & & & & \\
\hline Dusky dolphin & & & & \\
\hline Orca (killer whale) & & & & \\
\hline Southern sea lion & & & & \\
\hline Southern elephant seal & & & & \\
\hline Magellanic penguin & & & & \\
\hline Other (please list): & & & & \\
\hline
\end{tabular}

\begin{tabular}{|l|l|l|}
\hline Local sites & & \\
\hline Puerto Madryn & & \\
\hline Puerto Pirámides & & \\
\hline Península Valdés & & \\
\hline El Doradillo & & \\
\hline Punta Tombo visit \\
\hline Playa Unión & & \\
\hline Punta Loma & & \\
\hline Punta Ninfas & & \\
\hline
\end{tabular}




\section{Section II: Personal Information}

First, I would like to know a little bit more about you and your family. This information will help us understand what type of people visit Peninsula Valdes.

All information is confidential and anonymous - we will not ask for your name or address.

1. How old are you?

18 a 24

25 a 34

35 a 44

45 a 54

55 a 64

65 or older

2. From the list of ranges below, please select your annual household income.

\begin{tabular}{|c|c|c|c|c|c|}
\hline \multicolumn{2}{|c|}{ U.S. Dollars (U\$S) (annual) } & \multicolumn{2}{|c|}{ Argentine pesos (\$) (monthly) } & \multicolumn{2}{|c|}{ Euro (€) (annual) } \\
\hline $\mathbf{z}$ & Less than U\$S 10,000 & K & Less than $\$ 5,000$ & $\mathbf{Y}$ & Less than $€ 5,000$ \\
\hline J & $\$ 10,000-24,999$ & $\mathbf{P}$ & $\$ 5,000-\$ 7,999$ & B & $€ 5,000-11,999$ \\
\hline $\mathbf{T}$ & $\$ 25,000-49,999$ & $\mathbf{L}$ & $\$ 8,000-11,999$ & $\mathbf{R}$ & $€ 12,000-17,999$ \\
\hline v & $\$ 50,000-74,999$ & M & $\$ 12,000-\$ 14,999$ & N & $€ 18,000-23,999$ \\
\hline D & $\$ 75,000-99,999$ & C & More than $\$ 15,000$ & 0 & $€ 24,000-29,999$ \\
\hline u & $\$ 100,000-149,999$ & & & G & $€ 30,000-35,999$ \\
\hline \multirow[t]{4}{*}{ H } & More than U\$S 150,000 & & & A & $€ 36,000-59,999$ \\
\hline & & & & $\mathbf{Q}$ & $€ 60,000-89,999$ \\
\hline & & & & $\mathbf{S}$ & $€ 90,000-120,000$ \\
\hline & & & & $\mathbf{E}$ & More than $€ 120,000$ \\
\hline
\end{tabular}

3. In what sector of the economy do you work?

For example, manufacturing, retail, health, tourism, agriculture, etc.

4. What is your highest level of education?

_Primary ( $1-8$ years)

Secondary ( $9-12$ years)

_ Associate's degree

College (Bachelor's degree or equivalent)

__ Graduate school (Master's degree, PhD, or equivalent)

5. What is your household size?

6. Gender: $[\mathrm{M} / \mathrm{F}]$ 


\section{Section III: Travel Cost Questions}

Now we would like to know more about your travel plans and costs. This will help us understand why and how people arrive to Peninsula Valdes and how much they spend in order to travel here.

1. What is the primary purpose of your trip?

Work Friends and Family Leisure and Recreation

2. Which activities, if any, do you plan to participate in during your trip?

$\begin{array}{llll}1 & \text { Bicycle Touring } & 8 & \text { Day trip to Peninsula Valdes } \\ 2 & \text { Camping } & 9 & \text { Scuba diving } \\ 3 & \text { Hiking } & 10 & \text { Visit the Ecocentro } \\ 4 & \text { Whale watching } & 11 & \text { Kayaking } \\ 5 & \text { Dolphin watching } & 12 & \text { Wind surfing } \\ 6 & \text { Penguin excursion } & 13 & \text { Visit the Estancias } \\ 7 & \text { Close encounter with elephant seals } & 14 & \text { Other, please list: }\end{array}$

3. Who are you traveling with on this trip?

Family Friends Tour group Alone

4. Where did you travel to Puerto Madryn from?

5. How did you travel to Puerto Madryn?

Car Bus Plane Other

6. What was the cost for this trip (for example, airfare, bus ticket)?

7. How much do you plan to spend on excursions to view wildlife at this site?

8. How many days will you spend in Puerto Madryn?

9. What other sites are you visiting on this trip in Argentina? Please rank these sites plus Peninsula Valdes from most important (1) to least important.

If you are visiting more than 5 , please choose the 5 most important.

Site Rank 


\section{Section IV: Travel Packages}

I would like to pose a number of different possible excursions to you. I would like to remind you that any money spent on the trips you select could not be spent on any other trips or purchases.

All prices are listed in Argentine pesos

If you had the time, which trips, from the five listed below, would you take? You may select one trip, more than one trip, or none at all.

Trip 1

Price: $\$ 800$

A trip designed to see killer whales (orcas).

Trip 2

Price: $\$ \mathbf{6 5 0}$

A trip designed to see southern right whales.

Trip 3

Price: $\$ \mathbf{5 0 0}$

A trip designed to see dusky dolphins.

Trip 4

Price: $\$ \mathbf{5 5 0}$

A trip designed to see Magellanic penguins.

Trip 5

Price: $\$ \mathbf{1 5 0}$

A trip designed to see southern elephant seals.

1. How certain are you that you would see the animal in the trip or trips selected?

1 - not at all certain

2 - slightly certain

3-somewhat certain

4 - moderately certain

5 - very certain

2. Do you believe that you can see other animals besides the one being guaranteed on that trip?

[YES / NO ] 


\section{Section V: Environmental Management Plan in Peninsula Valdes}

1. What environmental problems, if any, have you heard of in this region?

2. How familiar are you with gull attacks on whales?

$$
\begin{aligned}
& 1 \text { - not at all familiar } \\
& 2 \text { - slightly familiar } \\
& 3 \text { - somewhat familiar } \\
& 4 \text { - moderately familiar } \\
& 5 \text { - very familiar }
\end{aligned}
$$

Before you respond to the following questions, I would like to remind you that any money you would spend on the following management plans would reduce the amount of money you have available to spend on other such plans or purchases.

There is evidence that kelp gulls, the most abundant bird in the area, have been attacking whales for food. Recently, government authorities in the province have decided to implement management actions to mitigate gull attacks on the whales.

If it cost $\$ 15$ to reduce the kelp gull population, would you pay this amount to as an additional charge included in the entrance fee, with sole purpose of being used to reduce the kelp gull population?

$$
\text { [YES / NO ] }
$$

Suppose, instead, that there is Management Plan A:

Improve management of the local disposal waste site so that it is no longer a feeding site for gulls.

How much would you pay for this program?

Suppose that Management Plan A is not sufficient to reduce the Kelp gull population.

Instead, there is Management Plan B:

Reduce the gull population by shooting the 'attacker gulls'.

Now, how much would you pay for this program?

\section{Comments}

If you have any questions or comments, please write them here:

\section{The End}

Thank you for taking the time to answer our questions! We really appreciate your help in this study. We hope you enjoy your visit to Peninsula Valdes!

If you have any questions, you can send an e-mail to the principal researcher, Stephanie Stefanski

(Stephanie.Stefanski@yale.edu ) 


\section{References}

Arrow, K., Solow, R., Portney, P.R., Leamer, E.E., Radner, R., Schuman, H., 1993. Report of the NOAA Panel on Contingent Valuation.

Byrnes, T.A., Warnken, J., 2006. Greenhouse gas emissions from marine tours: a case study of Australian tour boat operators. J. Sustainable Tourism 14 255-270. http://dx.doi.org/10.1080/09669580608669058.

Coscarella, M.A., Dans, S.L., Crespo, E.A., Pedraza, S.N., 2003. Potential impact of unregulated dolphin watching activities in Patagonia. J. Cetacean Res. Manage 5, 77-84.

Dans, S.L., Alonso, M.K., Crespo, E.A., Pedraza, S.N., García, N.A., 2003. Interactions between marine mammals and high seas fisheries in Patagonia: an integrated approach. In: Gales, N., Hindell, M., Kirkwood, R. (Eds.), Marine Mammals: Fisheries, Tourism and Management Issues. CSIRO, Collingwood, VIC, pp. 88-103.

Davenport, J., Davenport, J.L., 2006. The impact of tourism and personal leisure transport on coastal environments: a review. Estuarine Coast. Shelf Sci. 67, 280-292. http://dx.doi.org/10.1016/j.ecss.2005.11.026.

Depondt, F., Green, E., 2006. Diving user fees and the financial sustainability of marine protected areas: opportunities and impediments. Ocean Coast. Manage 49, 188-202. http://dx.doi.org/10.1016/j.ocecoaman.2006.02.003.

Dixon, J.A., Hof, T. Van , 1993. October 1993 Ecology and Microeconomics as "Joint Products": The Bonaire Marine Park in the Caribbean as "Joint Products": The Bonaire Marine Park in the Caribbean October 1993.

Fazio, A., Bertellotti, M., Villanueva, C., 2012. Kelp gulls attack Southern right whales: a conservation concern? Mar. Biol 159, 1981-1990. http://dx.doi.org/ 10.1007/s00227-012-1985-7.

Gandini, P.A., Frere, E., Pettovello, A.D., Cedrola, P.V., 2011. Interaction between Madellanic Penguins and Shrimp Fisheries in Patagonia, Argentina. Condor (101), 783-789.

Haab, T.C., McConnell, K.E., 2003. Valuing Environmental and Natural Resources: The Econometrics of Non-Market Valuation. Edward Elgar, Cheltenham.

Holden, A., 2008. Environment and tourism (In: Environment and Tourism). Routledge, New York, NY, pp. 1-24.

Kuper, D., 2009. Turismo y preservación ambiental: el desarrollo turístico de Península Valdés, Provincia del Chubut. PASOS 7, 85-97.

Lisnizer, N., Garcia-Borboroglu, P., Yorio, P., 2011. Spatial and temporal variation in population trends of kelp gulls in northern Patagonia, Argentina. EMU 111, 259. http://dx.doi.org/10.1071/MU11001.

Loomis J. and Santiago L., Economic valuation of beach quality improvements: comparing incremental attribute values estimated from two stated preference valuation methods, Coastal Management 41, 2013, 75-86,http://www.tandfonline.com/doi/abs/10.1080/08920753.2012.749754.

Medina, L.K., 2005. Ecotourism and certification: confronting the principles and pragmatics of socially responsible tourism. J. Sustainable Tourism 13, 281-295. http://dx.doi.org/10.1080/01434630508668557.
Naidoo, R., Adamowicz, W.L., 2005. Economic benefits of biodiversity exceed costs of conservation at an African rainforest reserve. Proc. Natl. Acad. Sci. U.S.A. 102, 16712-16716. http://dx.doi.org/10.1073/pnas.0508036102.

Ormsby, A., Mannle, K., 2006. Ecotourism benefits and the role of local guides at Masoala National Park, Madagascar. J. Sustainable Tourism 14, 271-287.

Peters, H., Hawkins, J.P., 2009. Access to marine parks: a comparative study in willingness to pay. Ocean Coast. Manage 52, 219-228. http://dx.doi.org/ 10.1016/j.ocecoaman.2008.12.001.

Ransom, K.P., Mangi, S.C., 2010. Valuing recreational benefits of coral reefs: the case of Mombasa Marine National Park and Reserve, Kenya. Environ. Manage. 45, 145-154. http://dx.doi.org/10.1007/s00267-009-9402-9.

Reid-Grant, K., Bhat, M.G., 2009. Financing marine protected areas in Jamaica: an exploratory study. Mar. Policy 33, 128-136. http://dx.doi.org/10.1016/j. marpol.2008.05.004.

Rowntree, V., Uhart, M., Sironi, M., Chirife, a, Di Martino, M., La Sala, L., Musmeci, L. Mohamed, N., Andrejuk, J., McAloose, D., Sala, J., Carribero, a, Rally, H., Franco, M. Adler, F., Brownell Jr, R., Seger, J., Rowles, T., 2013. Unexplained recurring high mortality of southern right whale Eubalaena australis calves at Península Valdés Argentina. Mar. Ecol. Prog. Ser. 493, 275-289. http://dx.doi.org/10.3354/ meps10506.

Rowntree, V.J., McGuinness, P., Marshall, K., Payne, R., Sironi, M., 1998. Increased Harassment of right whales (Eubalaena australis) by kelp gulls (Larus dominicanus) at Península Valdés, Argentina. Mar. Mammal Sci. 14, 99-115.

Schluter, R., 1999. Sustainable tourism development in South America: the case of Patagonia, Argentina. In: Pearce, D.G. (Ed.), Tourism Development: Contemporary Issues. Routledge, New York, NY, pp. 176-191.

Sironi, M., Rowntree, V.J., Di Martino, M., Chirife, A., Bandieri, L., Beltramino, L. Franco, M., Uhar, 2011. Southern right whale mortalities at Península Valdés, Argentina: updated information for 2010-2011. J. Cetacean Res. Manage, 1-5.

Sironi, M., Rowntree, V.J., Snowdon, C.T., Valenzuela, L., Marón, C., 1998. Kelp gulls (Larus dominicanus) feeding on southern right whales (Eubalaena australis) at Península Valdés, Argentina: updated estimates and conservation implications. J. Cetacean Res. Manage, 1-12.

Thomas, P.O., 1988. Kelp gulls, Larus dominicanus, are Parasites on flesh of the right whale, Eubalaena australis. Ethology 79, 89-103.

Thur, S.M., 2010. User fees as sustainable financing mechanisms for marine protected areas: an application to the Bonaire National Marine Park. Mar Policy 34, 63-69. http://dx.doi.org/10.1016/j.marpol.2009.04.008.

Uyarra, M.C., Gill, J. a., Côté, I.M., 2010. Charging for nature: marine park fees and management from a user perspective. Ambio 39, 515-523. http://dx.doi.org 10.1007/s13280-010-0078-4.

Walpole, M.J., Goodwin, H.J., Ward, K.G.R.R., 2001. Pricing policy for tourism in protected areas: lessons from Komodo National Park, Indonesia. Conserv. Biol. $15,218-227$. 